\title{
A Comparative Static Analysis of Some Monetarist Propositions
}

\author{
by ROBERT H. RASCHE
}

Robert H. Rasche is Associate Professor of Economics at Michigan State University, East Lansing, Michigan. During the 1971-72 academic year, Professor Rasche was a visiting scholar at the Federal Reserve Bank of St. Louis. The following paper evolved out of discussions and seminars with the staff of this Bank during his visit. The paper is presented in order to foster further discussion of those propositions generally associated with the monetarist framework of analysis.

The element of time is a chief cause of those difficulties in economic investigation which make it necessary for man with his limited powers to go step by step; breaking up a complex question, studying one bit at a time, and at last combining his partial solutions into a more or less complete solution of the whole riddle. In breaking it up, he segregates those disturbing causes, whose wanderings happen to be inconvenient, for the time in a pound called Ceteris Paribus.

$$
\text { - Alfred Marshall }
$$

The typical textbook approach to macroeconomic analysis is almost completely barren with respect to what has become characterized as the "monetarist position" on the effects of monetary and fiscal policy actions. These propositions might be summarized as follows:

(1) the long-run impact of monetary actions is on nominal variables, such as nominal GNP, the general price level, and nominal interest rates;

(2) long-run movements in real economic variables, such as output and employment, are little infuenced, if at all, by monetary actions;

(3) in the short run, actions of the central bank exert an impact on both real and nominal variables;

(4) fiscal actions have little lasting influence on nominal GNP, but can affect short-run movements in output and employment; and

(5) Government expenditures financed by taxes or borrowing from the public tend to crowd out over a fairly short period of time, an equal amount of private expenditures. ${ }^{1}$

These propositions have been gleaned from Leonall C. Andersen, "A Monetarist View of Demand Management: The United States Experience," this Review (September 1971), pp. 3-11.
It would seem that a static analytic framework could be developed which could shed some light on the theoretical underpinnings of monetarism, although the mode of analysis is obviously insufficient to cope with the dynamic propositions which are associated with this school. Unfortunately the literature is extremely scarce. Milton Friedman has set forth a static framework, and alleges that the differences between monetarists and post-Keymesians have to do with assumptions about price (and wage) behavior. Monetarism, he alleges, assumes that the aggregate price level is determined in such a way as to clear all markets in the long run. For the short run, he alleges that neither the monetarist nor the fiscalist has a satisfactory theory of the response of real output and the general price level to monetary shocks. Unfortunately, Friedman's excursion into dymamics and differential equations is difficult, if not impossible, to relate to individual market forces. ${ }^{2}$

Thus, the issue remains unsettled. On the one hand, we are left without a clearly specified analytical framework for the monetarist approach which can be contrasted with the well-developed static income determination model. On the other hand, and even more importantly, there is no general model which can produce the post-Keynesian model as a particular case, and the monetarist and classical models as alternative cases. Such a framework is useful in order to discriminate between alternative hypotheses and to construct empirical tests which have the potential to refute one, or both, positions.

\footnotetext{
Milton Friedman "A Theoretical Framework for Monetary Analysis," Journal of Political Economy (March/April 1970), pp. $193-238$.
} 
This study attempts to develop a general model by examining equilibria which differ by the length of the "run." This Marshallian tool should be clearly defined as applying to the behavior which is assumed to be embodied in the ceteris paribus assumptions: the more behavior which is embodied in ceteris paribus, the shorter the "run." Traditional macrostatics has been of the Marshallian "short-run" variety; that is, the real capital stock has been held constant. This leads to some unfortunately confusing terminology. Most of the traditional analysis from which the "long-run" monetarist propositions can be gleaned is not long-run analysis in the Marshallian sense. At the risk of adding further confusion to the discussion we shall stay with the traditional short-run definition as the "short run," and compare the results of this model with those of an even shorter run, or "momentary run" model.

It is well established that a Patinkin-type four market model (labor services, commodities, bonds, and money), under assumptions of complete price flexibility, absence of money illusion, unitary elasticity of price expectations, and perfect information on market prices, will exhibit propositions (1), (2), and (5) above, in comparison of "short-run" equilibria which differ because of a shock to some policy variable. ${ }^{3}$ However, these analyses have nothing to contribute to the discussion of propositions (3) and (4).

\section{Basic Elements of Model}

More than a decade ago, it appears that the assumption of perfect information on prices was implicitly relaxed in some of the research work of leading monetarists. Friedman, in his work on the demand for money, distinguished between the current commodity price index, and a longer-run concept which he called the "permanent price level." He argued that:

. . . holders of money presumably judge the "real" amount of cash balances in terms of the quantity of goods and services to which the balances are equiv. alent, not at any given moment of time, but over a sizable and indefinite period; that is, they evaluate them in terms of "expected" or "permanent" prices, not in terms of the current price level. This

\footnotetext{
${ }^{3}$ For a derivation of these propositions and a discussion of the effects of the presence or absence of government bonds ir the model, see Don Patinkin, Money, Interest, and Prices: An Integration of Monetary and Valte Theory, and ed. (New York: Harper and Row, 1965), chap. 10; Robert L. Cronch, Macroeconomics (New York: Harcourt, Brace and Jovanovich, 1972), chaps. 6-9; and Franco Modigliant, "The Monetary Mechanism and Its Interaction with Real Phenomena," Retiew of Economics and Statistics, Supplement (February 1963), pp. $79-107$
}

consideration does not, of course, rule ont some adjustment to temporary movements in prices. 4

Recently, following the pioneering work of George Stigler and Armen A. Alchian, considerable theoretical and empirical work on labor market behavior and the Phillips curve has been produced. ${ }^{5}$ These studies assume that workers do not possess perfect information on the wages available to them in return for their labor services, and it is costly for workers to search out information on the opportunities available to them. Within this framework it is necessary to distinguish between the nominal wage rate which is actually offered for labor services at a point in time, $W$, and the wage rate which is perceived by suppliers of labor services, $W_{\mathrm{e}}$. In this paper we employ a wage rate information parameter, $\lambda_{1}$, to relate the perceived wage rate to the currently offered rate and an exog* enous, or predetermined, component, $W_{0}$.

The relationship we postulate is:

$$
\mathrm{W}_{\mathrm{e}}=\mathrm{w}^{\lambda_{1}}\left(\mathrm{~W}_{\mathrm{o}}\right)^{1-\lambda_{1}}
$$

so the perceived nominal wage rate is a geometric average of the current wage rate and a predetermined wage rate, presumably based on the history of previous wage experience. If the wage information parameter, $\lambda_{1}$, is set equal to 1.0 , there is costless information and the perceived wage rate is the curtent nominal wage. At the other extreme, if $\lambda_{1}$ is set equal to zero, information about the current wage rate has an infinite price and there is total ignorance of current market conditions.

This cost of information approach can be extended to the commodity market. We assume that households make their consumption and portfolio decisions on the basis of their perceived commodity price index, $P_{e}$, which can differ from the actual commodity price index if information on commodity prices is imperfect and costly to gather. ${ }^{6}$ Analogous to the case of the wage rate, we postulate a price information parameter, $\lambda_{2}$, which relates the perceived price index to the current price index as follows:

"Milton Friedman, "The Demand for Money: Some Theoreti" cal and Empirical Results," Journal of Political Economy (August 1959), pp. 327-351.

"George J. Stigler, "Information in the Labor Market," Journal of Political Economy, Supplement (October 1962), pp. 94105, and Armen A. Alchian, "Information Costs, Pricing, and Resource Unemployment" "Edmund Phelps et al., Microeconomic Foundations of Employment and Inflation Theory (New York: Norton, 1970) pp. 27-52.

${ }^{6}$ For simplicity, we assume firms have zero information costs with respect to wages and prices. 
Table I

Equations for the Complete Macroeconomic Model

(excluding a Government Sector)

\begin{tabular}{|c|c|c|c|}
\hline & Equation & Name & Market \\
\hline (I) & $N^{d}=N^{d}\left(\frac{W}{P}, \bar{K}\right.$ & Labor demand function & \\
\hline (II) & $\mathrm{N}^{s}=\mathrm{N}^{\mathrm{s}}\left(\frac{\mathrm{W}_{\mathrm{e}}}{\mathrm{P}_{e}}\right)$ & Labor supply function & Labor market \\
\hline (III) & $\mathrm{N}^{\mathrm{a}}=\mathrm{N}^{\mathrm{s}}=\mathrm{N}$ & Labor market equilibrium condition & \\
\hline (IV) & $\mathrm{X}^{\mathrm{s}}=\mathrm{X}^{\mathrm{s}}(\mathrm{N}, \overline{\mathrm{K}})$ & $\begin{array}{l}\text { Production (or commodity supply) } \\
\text { function }\end{array}$ & \multirow{5}{*}{ Commodity market } \\
\hline (V) & $\mathrm{C}=\mathrm{C}\left(\mathrm{X}_{\mathrm{d}}, \frac{\mathrm{V}}{\mathrm{P}_{\mathrm{e}}}\right)$ & $\begin{array}{l}\text { Commodity demand function for con- } \\
\text { sumption (the consumption function) }\end{array}$ & \\
\hline (VI) & $I=I(X, r)$ & $\begin{array}{l}\text { Commodity demand function for in- } \\
\text { vestment (the investment function) }\end{array}$ & \\
\hline (VII) & $X=C+I$ & $\begin{array}{l}\text { Total (or aggregate) commodity de- } \\
\text { mand function }\end{array}$ & \\
\hline (VIII) & $X=X^{s}$ & $\begin{array}{l}\text { Commodity market equilibrium con- } \\
\text { dition }\end{array}$ & \\
\hline
\end{tabular}

(IX)

(X)

$\frac{\mathrm{B}^{\mathrm{d}}}{\mathrm{r}_{\mathrm{t}}}=\mathrm{B}^{\mathrm{a}}\left(\mathrm{X}_{\mathrm{a}}, \frac{\mathrm{l}}{\mathrm{r}}, \frac{\mathrm{V}}{\mathrm{P}_{\mathrm{e}}}\right) \quad$ Bond demand function

(X)

$\frac{\mathrm{B}^{\mathrm{s}}}{\mathrm{rP}}=\mathrm{B}^{s}\left(\mathrm{X}^{s}, \frac{\mathrm{l}}{\mathrm{r}}, \frac{\mathrm{V}}{\mathrm{P}}\right) \quad$ Bond supply function

Bond market

(XI)

$\mathrm{B}^{\mathrm{d}}=\mathrm{B}^{\mathrm{s}}$

Bond market equilibrium condition

(XII)

$\frac{\mathrm{M}^{\mathrm{d}}}{\mathrm{P}_{\mathrm{e}}}=\mathrm{L}\left(\mathrm{X}, \mathrm{r}, \frac{\mathrm{V}}{\mathrm{P}_{\mathrm{e}}}\right) \quad$ Money demand function

(XIII)

$\mathrm{M}^{\mathrm{d}}=\overline{\mathrm{M}^{\mathrm{s}}}$
Money market equilibrium condition

and (exogenous) money supply finc-
Money market
(XIV)

(XV)

(XVI)

(XVII)

(XVIII)

$(\mathrm{XIX})$

$$
S=X^{s}-C
$$$$
\mathrm{Y}=\mathrm{PX}^{\mathrm{s}}
$$$$
V=P \bar{K}+\overline{\mathbf{M}}^{s}
$$$$
\mathrm{X}_{\mathrm{d}}=\frac{\mathrm{Y}}{\mathrm{P}_{\mathrm{e}}}
$$

$$
W_{e}=w^{\lambda_{1}} W_{0}^{\left(1-\lambda_{1}\right)}
$$$$
\mathrm{P}_{\mathrm{e}}=\mathrm{P}^{\lambda_{2}} \mathrm{P}_{0}^{\left(1-\lambda_{2}\right)}
$$

\section{Definition of saving}

Definition of money income

Definition of money wealth (net assets or net worth)

Definition of real perceived disposable income

Definition of perceived wage rate

Definition of perceived price level
Definitions of supplementary variables 


$$
\mathrm{P}_{\mathrm{e}}=\mathbf{P}_{\left(\mathrm{P}_{0}\right)^{1-\lambda_{2}}}^{\lambda_{2}}
$$

Again the perceived commodity price index is a geometric average of the current price index and an exogenously determined price level. When $\lambda_{2}$ equals one, information on the commodity price is free, and all information on current prices can be incorporated into decision making. When $\lambda_{2}$ is equal to zero the cost of information is infinite, and no current market behavior is incorporated into decision making.

Once we allow the perceived price level and perceived wage rate to differ from the respective current market value, we must explicitly introduce $P_{e}$ and $W_{0}$ into the model. This is indicated in Table $I$, where the labor supply function of households is expressed as a function of the perceived real wage rate $\left(\frac{W_{e}}{P_{e}}\right)$, real consumption demand is a function of perceived real net worth $\left(\begin{array}{c}\mathrm{V} \\ \overline{\mathrm{P}_{\mathrm{e}}}\end{array}\right)$ and perceived real disposable income, as are real bond demand and the demand for real cash balances. If we interpret $P_{e}$ as equivalent to Friedman's "permanent" price index concept, the money demand equation (equation XII in Table I) is the money demand function used by Friedman with the exception of his use of a per capita specification and an explicit functional form. ${ }^{7}$ All other functions are specified exactly as in the Patinkin model. In particular it should be noted that the interest elasticity of the demand for real cash balances has not been constrained to zero.

First, the behavior of the labor market has to be considered. As indicated in Figure I, there is a single labor demand curve plotted as a function of the prevailing real wage $\left(\frac{\mathrm{W}}{\mathrm{P}}\right)$. We have to analyze how the labor supply curve interacts with this labor demand curve. Consider a situation in which the movement from one equilibrium to another involves a rise in the commodity price index, P. If, under these circumstances, the labor supply function shifts to the right, from $\mathrm{N}_{1}$ to $\mathrm{Ns}_{2}$, then the new equilibrium of the system is characterized by higher employment and a lower real wage rate than the initial equilibrium. Since employment is higher, real output is also higher in the new equilibrium relative to the initial equilibrium.

7Friedman, "The Demand for Money," pp. 327-351.

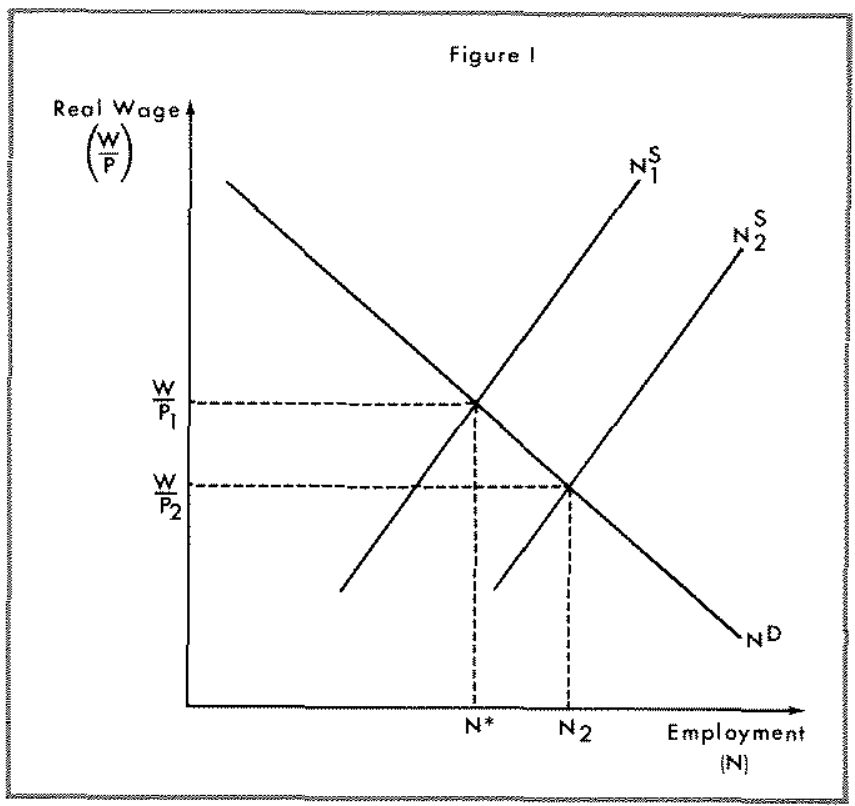

It can be shown that a sufficient condition for the labor supply curve to shift to the right in the real wage-employment plane in response to increases in the commodity price index is that $\lambda_{1}$, the information parameter for the perceived nominal wage rate, be greater than $\lambda_{2}$, the information parameter for the perceived commodity price index. ${ }^{8}$ In the analysis which follows, we shall characterize the "momentary" equilibrium as one in which information on both wages and prices is not free - that is, $0<\lambda_{2}<\lambda_{1}$ $<1$. The short-run equilibrium will be characterized by perfect information on both wages and prices - that is $\lambda_{1}=\lambda_{2}=1$. In the short run, there are no shifts of the labor supply eurve in response to changes in commodity prices and the equilibrium level of employment remains at $\mathrm{N}^{*}$, the initial equilibrium level. This phenomenon appears to be identical to that conceived by Friedman in his discussion of the natural unemployment rate. ${ }^{9} \mathrm{~N}^{*}$ could be termed the "natural level of employment" in this static model.

\section{Chrnges in the Money Stock}

It remains to be seen how the model reacts in a momentary equilibrium, after the money stock has changed. A monetarist scenario has been provided by Friedman:

... suppose . . that the "natural" [unemployment] rate is higher than 3 per cent. Suppose also that we

\footnotetext{
${ }^{8}$ For a proof of this proposition see Appendix A, which is available only in the reprint to this aticle.

9Milton Friedman, "The Role of Monetary Policy," American Economic Review (March 1968), p. 8.
} 
start out at a time when prices have been stable and when unemployment is higher than 3 percent. Accordingly, the [monetary] authority increases the rate of monetary growth. This will be expansionary. By making nominal cash balances higher than people desire, it will tend initially to lower interest rates and in this and other ways to stimulate spending. Income and spending will start to rise.

To begin with, much of most of the rise in income will take the form of an increase in output and employment rather than in prices. People have been expecting prices to be stable, and prices and wages have been set for some time in the future on that basis. It takes time for people to adjust to a new state of demand. Producers will tend to react to the initial expansion in aggregate demand by increasing output, employees by working longer hours, and the unemployed, by taking jobs now offered at former nominal wages. This much is pretty standard doctrine.

But it describes only the initial effects. Because selling prices of products typically respond to an unanticipated rise in nominal demand faster than prices of factors of production, real wages received have gone down - though real wages anticipated by employees went up, since employees implicitly evaluated the wages offered at the earlier price level. Indeed, the simultaneous fall ex post in real wages to employers and rise ex ante in real wages to employees is what enabled employment to increase. ${ }^{10}$

This is precisely the behavior implicit in our fourmarket model. The increase in the money stock initially causes an excess supply in the "money market," an excess demand for bonds, and an excess demand for commodities through increased consumption demand, since both $\left(\frac{V}{P_{\star}}\right)$ and $\left(\frac{V}{\bar{P}}\right)$ are larger. In the momentary equilibrium, real output, commodity prices, and money wages are all higher than their initial equilibrium values. ${ }^{11}$ However, the change in $W$, the money wage rate, is less than proportional to the change in $P$, and the actual real wage rate declines. The real wage perceived by suppliers of labor services $\left(\frac{W_{e}}{P_{e}}\right)$, increases as long as the cost of obtaining information about prices is greater than the cost of obtaining information about wages $\left(\lambda_{2}<\right.$ $\left.\lambda_{1}\right)$. Thus, the labor supply curve shifts to the right. The momentary equilibrium results correspond quite closely to the monetarist scenario outlined by Friedman and to the third proposition taken from Andersen.

\footnotetext{
${ }^{10}$ Friedman, "The Role of Monetary Policy," pp. 9-10.
}

11The mathematical proof of these propositions, with a statement of sufficiency conditions, can be found in Appendix $B$, which is included only in the reprint to this article.
Table II

\section{Notation}

I. Endogenous Variables

A. Flow variables

1. $\mathrm{N}$, demand for labor (labor services per time period)

2. $\mathrm{N}^{8}$, supply of labor (labor services per time period)

3. $X^{s}$, real income (total output of commodities per time period)

4. C, real consumption (commodities consumed per time period)

5. I, real investment (commodities invested, added to the capital stock, per time period)

6. $\mathrm{X}$, real aggregate demand (total demand for commodities per time period)

7. S, real saving (output of commodities not consumed per time period $)$

8. $Y$, money income (money value of total output of commodities per time period)

9. $\mathrm{X}_{\mathrm{a}}$, perceived real disposable income

B. Stock variables

1. Bd, demand for bonds (number of bonds de. manded to hold)

2. Bs, supply of bonds (number of bonds planned to be outstanding)

3. $M$, demand for nominal money (number of dollars demanded to hold)

4. $V$, nominal wealth, or net worth (dollar value of real assets and money)

C. Price variables

1. $P$, the absolute, or nominal, price level (the price of commodities)

2. W, the absolute, or nominal, wage level the price of labor or wage rate)

3. $1 / r$, the absolute, or nominal, price of bonds

II. Exogenous Variables

A. Flow variables

1. $\mathrm{G}$, government demand for commodities (commodities per time period)

2. $\$ \mathrm{Br}$, interest cost of the outstanding government debt (equals $\mathrm{Bs}^{\mathrm{s}}$ times one dollar per time period)

3. $T$, real tax receipts (per time period)

B. Stock variables

1. $\overrightarrow{\mathbf{K}}$, the real capital stock the number of commodities that have been acctimulated up to the beginning of the present time period)

2. $\mathrm{M}^{\mathrm{s}}$, the supply of nominal money (the number of dollars avalable to be held)

3. Bs supply of government bonds (number of govemment bonds outstanding)

C. Price variables

1. Po, predetermined component of the perceived price level

2. $W_{0}$, predetermined component of the perceived wage rate

An interesting question remains on the extent to which prices respond to a change in the money stock in this momentary equilibrium. In particular, we wish to consider the percentage change in the commodity price index generated by a one percent change in the money stock. In Appendix B (included only in 
reprint) it is shown that when (1) a set of sufficient conditions for a positive change in real output in response to a positive change in the money stock is satisfled, and (2) the money demand function is elastic with respect to perceived real disposable income, then the elasticity of the price level with respect to the money stock is less than one. Hence, the change in the price level between the two equilibrium states is less than proportional to the change in the money stock.

This result allows some interesting comparative static results to be obtained between the momentary equilibrium and the short-run equilibrium in which perceptions have been allowed to adjust fully to the change in the actual price level. In this state money can be shown to be neutral. Therefore, in comparison to the initial equilibrium, the percentage change in the commodity price index mut be equal to the percentage change in the money stock. Thus, $\mathrm{P}$ must be higher in the short-run equilibrium than it is in the momentary equilibrium for a given change in the money stock. On the other hand, in the short-run equilibrium real output and employment must be unchanged from the initial equilibrium and, therefore, employment must be lower than in the momentary equilibrium.

This simultaneous increase in the price level and reduction in employment is a close analog to the dynamic phenomena of increasing inflation and increasing unemployment which perplexed economists and policymakers during 1970-71. In the model, the cause of this type of behavior is not price rigidity or monopolistic market power, but rather the correction of false perceptions.

\section{Open Market Operations in Eristing Covermment Debt}

The analysis of the previous section applies to an economy in which there is no government debt, and money has to be created by some artificial construct such as throwing it out of airplanes. This is frequently the convention with textbook models. More realistically, the model should be expanded to include a government sector and an outstanding stock of govermment debt. In such an economy, open market operations can be conducted with the monetary authorities purchasing or selling government debt in exchange for cash balances. The modifications to the
$\mathrm{X}=\mathrm{C}+\mathrm{I}+\mathrm{G} \quad$ Aggregate commodity

demand function

Bond market equilibrium condition

Definition of money wealth

Definition of real perceived disposable income

$\mathrm{B}^{\mathrm{d}}=\mathrm{B}^{\mathrm{s}}+\mathrm{B}^{\mathrm{z}}$

$\mathrm{V}=\overline{\mathrm{PK}}+\overline{\mathrm{M}^{\mathrm{s}}}+\frac{\mathrm{Bg}}{\mathrm{r}}$

$X_{d}=\frac{P}{P_{e}}(X-T)+\frac{\$ B g}{P_{e}}$
Table III
Modified Equations to Incorporate a Government
Sector in the Macroeconomic Model

Table III
Modified Equations to Incorporate a Government
Sector in the Macroeconomic Model

$\mathrm{dM}$

$\mathrm{P}(\mathrm{G}-\mathrm{T})+\$ \mathrm{BB}^{\mathrm{z}}=\frac{\mathrm{d \textrm {B } ^ { \mathrm { z } }}}{\mathrm{r}}+\mathrm{dM}$

equations of Table I, necessary to incorporate the government sector, are given in Table III.

There are three basic additions to the model of Table I. First, the commodity demand equation has to be expanded to incorporate the government demand for goods and services, G. Second, we assume that the public does not discount future tax liabilities which will be required to pay the interest on the outstanding debt, so that the value of the stock of government debt is a component of private wealth. Third, the definition of perceived real disposable income must be modified to allow for the taxing of income by the government, $\mathrm{T}$, and the payment of interest on the outstanding debt.

The remaining problem is to define what is meant by a pure open market operation. Open market operations are defined as exchanges of government debt and cash balances of equal value between the monetary authorities and the private sector of the economy. Unfortunately, we cannot leave the definition at this point. It is now well established that macroeconomic models frequently have been careless in the treatment of the relationships between government fiscal and monetary operations which are implicit in a financing constraint on the government sector. ${ }^{12}$ In the model developed here, the govemment must finance the difference between its tax receipts and the value of its purchases of goods and services plus the interest payments on the outstanding debt either by issuing new debt, or by printing new money. This relationship is indicated as the government financing constraint in Table III.

\footnotetext{
12Carl Christ, "A Simple Macroeconomic Model with a Government Budget Restraint," Journal of Political Economy
} (January/February 1968) pp. 53-67. 
Consider an initial equilibrium of the economy where the right hand side of the equation for the financing constraint is zero; that is, tax receipts just cover government expenditures and interest cost. Now consider an open market operation which changes the amount of government debt held by the public. Since debt and cash balances of equal value are exchanged in the transactions, if the right hand side of the financing constraint was zero initially, it remains zero. Since the stock of debt held by the private sector has changed, the left hand side of the equation can no longer sum to zero without some changes in either $G$ or $T$, to offset the direct effect on the financing constraint of the change in the interest cost, and the indirect effect of the change in value of government purchases and taxes through induced changes in commodity prices. We shall define a pure open market operation as an exchange of government debt and cash balances between the monetary authorities and the private sector, which is simultaneously accompanied by whatever change in $T$ is necessary to maintain the government financing constraint, with $\mathrm{G}$ remaining unchanged.

The effects of a pure open market operation in the momentary equilibrium are analyzed in Appendix C (included only in reprint). The sufficiency conditions for positive responses of real output, employment, and commodity prices to an open market operation which increases the stock of money held by the public are the same as those for the situation where the stock of money was increased in the absence of govermment debt.

It is well known that in the Patinkin-type model with which we are working, money will not be neutral in the short run in the presence of interest bearing govemment debt. Therefore, the response of prices to open market operations in the short run must be analyzed before we can determine that all of the results of the first model carry over to this case. ${ }^{13}$ There are no real output or employment responses relative to the initial equilibrium in this case, since the classical labor market behavior without any money illusion is present.

It can be shown that the conditions which are sufficient for a positive output response to an open market operation which increases the stock of money in the momentary equilibrium are also sufficient to insure that the elasticity of the price index to the increase in the money stock is greater in the short-run than in the

13This analysis is carried out in Appendix $D$, which is available only as part of the reprint to this article. momentary run. Thus, the result of the first model that prices are higher in the short-run relative to the momentary equilibrium, even though employment is lower between the two equilibria, carries over to the model including government debt in the presence of a pure open market operation.

\section{Fiscol Polloy: Tax Thanced Changes th Weal Cooemment Ixpendirures}

The conclusions for the comparative static impacts of fiscal policy in the momentary equilibrium are quite similar to those of monetary policy. A tax-financed increase in real government purchases of goods and services generates an initial excess demand in the commodity market which causes commodity prices to rise. The increased commodity price causes a shift of the labor supply function as in Figure $I$, since the same type of money illusion prevails here as in the monetary policy case. In the momentary equilibrium real output, employment, prices, and money wages are higher than in the initial equilibrium, but real wages are lower. In this case, since the stock of money has not changed, we can conclude unambiguously that the interest rate, $r$, must be higher for the "money" and bond markets to be restored to equilibrium.

It is well known that in the short-run equilibrium the increases in real government purchases and taxes do not have any impact on real output and employment. Hence, output and employment must be lower relative to the momentary equilibrium. Real government purchases, in the short run, "crowd out" an equal amount of real private expenditures. This "crowding out" comes about through increases in P and $\mathrm{r}$ which reduce both private consumption demand and private investment demand. Since in the short-run equilibrium, as compared to the initial equilibrium, $P$ is higher and $\mathrm{X}$ remains unchanged, "crowding out" does not in general occur in nominal terms. ${ }^{14}$

\footnotetext{
14Nominal "crowding out" is implied by Andersen's fourth proposition. It is not clear how generally this proposition is accepted among "monetarists". The implication of the St. Louis model (Leonall C. Andersen and Keith M. Carlson, "A Monetarist Model for Economic Stabilization," this Review (April 1970), pp. 7-25), is that changes in nominal high employment government expenditures, if unaccompanied by changes in the money stock, will ultimately leave nominal GNP unchanged. Since high employment government expenditures differ from actual government expenditures only by some adjustments to unemployment compensation, this equation might be interpreted as implying complete 'nominal crowding ont'. For a further defense of the nominal crowding out position see Roger $W$. Spencer and William P. Yohe, "The "Crowding Out" of Private Expenditures by Fiscal Policy Actions," this Review (October 1970), pp. 12-24.
} 
In this model, crowding out occurs in nominal terms only if $\mathrm{P}$ remains unchanged, and all the adjustment of private demand comes about through interest rate changes. This occurs only if additional assumptions are made about the nature of the demand for real cash balances. In particular, complete nominal "crowding out" of tax-financed changes in government purchases of goods and services oceurs in this model only if both the interest elasticity of the demand for real cash balances and the real wealth elasticity of the demand for real cash balances are equal to zero. In addition, the demand for real cash balances must be specified as a function of real output, and not real disposable income, to the extent that there exists a current real income elasticity of this function. Under these circumstances, if $\mathbf{P}$ were to rise (fall), the supply of real cash balances would decline (rise), but the demand for real cash balances would remain unchanged. Hence, any $P$ other than the initial $P$ would be inconsistent with equilibrium in the "money" market.

\section{Fiscrl Policy: Changes in Real Govermment Expenditures Financed by Sellng Debt or Prineing Money}

The impacts of changes in government expenditures financed by debt issue or money creation are similar to those of the tax finance case, but the magnitudes are different. In the debt financing case, there exists a problem of definition similar to that encountered in the open market operation discussed above. Changes in outstanding debt imply changes in interest costs. Also, to the extent that there are induced effects on the commodity price level, the value of government purchases of goods and services and the value of tax receipts are changed, upsetting the financing constraint. We have assumed that a debt-financed change in government expenditures is accompanied by changes in real taxes which leaves real disposable income in the short-run equilibrium unchanged from the initial equilibrium value. Using this convention, a situation of financing by printing money, which can be thought of as a debt financing situation simultaneously accompanied by a pure open market purchase of government debt, requires no change in taxes.

As noted above, the effects of changes in government expenditures on the commodity price level in the short-run equilibrium differ depending on the financing mode. In particular, debt financing has a smaller impact on the price level than printing money.
Further, the impact of a debt financed change in govermment expenditures on the price level is not zero, unless both the interest elasticity and the wealth elasticity of the demand for real cash balances are zero. Again, complete nominal crowding out of real government expenditures requires extreme assumptions in this model.

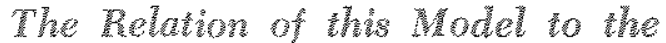

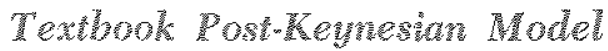

The model presented in Tables I and III has been discussed in terms of the monetarist propositions stated in the introduction. It has been shown that comparison of a momentary run, in which information costs are positive, with a short run, in which information is perfect, can produce conclusions similar to those alleged by the proponents of monetarism.

Consider a situation in which, no matter what the length of the run, households remain perfectly ignorant with respect to commodity prices $\left(\lambda_{2}=0\right)$. In contrast, assume households possess perfect information on money wages $\left(\lambda_{1}=1\right)$. The perceived real wage rate in all runs is then $\left(\frac{W_{\mathrm{e}}}{\mathrm{P}_{\mathrm{e}}}\right)=\left(\frac{\mathrm{W}}{\mathrm{P}_{\mathrm{o}}}\right)$, and the labor supply function states that the quantity of labor services supplied is a function solely of the nominal wage rate, regardless of the length of the run. This, however, is just the usual post-Keynesian assumption about the labor supply function.

Theoretical consistency suggests that these assumptions about the information parameters be carried over to the other household behavior functions. This implies that the consumption function and asset demand functions should not be homogenous of degree zero in money income, nominal wealth, and commodity prices. The post-Keynesian literature on these functions is not completely consistent on this interpretation. Modigliani states that the homogeneity restrictions should be applied to both the consumption functions and asset demand equations, even though the labor supply function depends only on the nominal wage rate. ${ }^{15}$

In empirical studies, the approach has been mixed. At least one study of the consumption function has taken the approach that the specification should allow for the existence of money illusion in the consumption function and the data should be allowed to in-

15Modigliani, "The Monetary Mechanism," pp. 79-107. 
dicate the result. ${ }^{16}$ More frequently, the homogeneity restrictions have been applied a priori. In the empirical literature on the money demand function, the approach has been less one sided, with both homogeneous and non-homogeneous functions prevalent in the literature. ${ }^{17}$

The assumption that $\lambda_{2}=0$ and $\lambda_{1}=1$ is of course just a particular case of the general case of $\lambda_{2}<\lambda_{1}$ $\leq \mathrm{I}$, which we use to characterize the momentary equilibrium case above. Thus, all of the results which were discussed for the momentary equilibrium are characteristic of the post-Keynesian case. Within this framework, the main difference between the postKeynesians and the monetarists appears to be how rapidly households develop correct perceptions of price and wage developments.

\section{The Telation of this Model to Oher Monetariat Lssues}

It was noted at the beginning of this analysis that the results which were generated from this framework would satisfy many of the monetarist propositions about the working of the macroeconomy. However, it was emphasized that this should not be considered as "the" monetarist model. In particular, there are many aspects of it which monetarists would allege are incomplete. Since the analysis is confined to comparative statics, nothing has been said, nor can anything be said, about real versus nominal interest rates.

In addition, the analysis is restricted to the fourmarket model which is usually presented, implicitly or explicitly, in the commonly used macroeconomics texts. This has been done purposefully in the attempt to maintain comparability. On the other hand, the model definitely will appear deficient to many monetarists because of this restriction. In particular, no banking sector has been explicitly developed, so all cash balances in the economy are high-powered money. Thus, all problems associated with the relationship between money and a monetary base concept are swept aside.

16William H. Branson and Alvin K. Klevorick, "Money Il" lusion and the Aggregate Consumption Function," American Economic Review (December 1969), pp. 832-49.

17See David Laidler, "The Rate of Interest and the Demand for Money: Some Empirical Evidence," Joumal of Political Economy (December 1966), pp. 543-555.
Recently, Karl Brunner and Allan Meltzer have alleged that the four-market model is an inadequate framework within which to discuss the working of the macroeconomy because it omits an essential market, the market for existing real capital. ${ }^{18}$ The analysis presented above could be extended to include an additional market and an additional price, that of existing assets. Obviously, such a model can have different implications on the results of various policy actions, and it is possible that a thorough analysis of such a model along the lines presented here would produce considerably more optimistic results for those who are persuaded that "nominal crowding out" of real government expenditures, in the absence of monetary financing, is an important feature of the economic picture.

\section{Conclusions}

All of the "monetarist" propositions about the results of monetary policy actions, and all but one of the propositions about the results of fiscal policy actions (the exception being nominal "crowding out"), have been derived without any explicit restriotions on the interest elasticity of the demand function for real cash balances. In particular, the results do not require that this elasticity be zero, either at momentary equilibrium or at short-run equilibrium. Rather, the propositions are derived from explicit and differing assumptions about price perceptions. Furthermore, the original model, with the labor supply curve replaced by the assumption of a permanently rigid money wage rate, is easily recognizable as the textbook "complete" Keynesian model.

The rather pessimistic conclusion suggested by this analysis is that a decade of academic debate on the relative stability of monetary velocity and the autonomous expenditure multiplier has been totally extraneous to the basic problem. On balance, the debate has probably been harmful to our understanding of the impact of alternative stabilization policies. The issues involved in these debates just do not discriminate between alternative hypotheses of macroeconomic behavior.

18Karl Brunner and Allan Meltzer, "Money, Debt, and Eco+ fomic Activity," Joumal of Political Economy (September/ October 1972), pp. 951-977.

Whis article and a forheoming algebraic appendit will be avallable in syring 1974 as Reprint No. 82. 